\title{
Evaluation of simple and adaptable feed ingredient mix for broiler chickens production
}

${ }^{1}$ Agbede, J. O., ${ }^{1}$ Aboyewa, O. D., ${ }^{1}$ Ayeni, A. O. and ${ }^{*, 1,2}$ Oloruntola, O. D.

${ }^{1}$ Department of Animal Production and Health,

The Federal University of Technology, Akure, Nigeria.

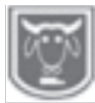

Abstract
${ }^{2}$ Department of Animal Science, Adekunle Ajasin University,

Akungba Akoko, Nigeria.

*Corresponding author: olugbenga.oloruntola@aaua.edu.ng, $+2348035841626$

A 42-day feeding trial was conducted to evaluate the simple and adaptable feed ingredient mix for broiler chickens' production. The four formulated diets were used as a straight diet with the fish meal (FM), groundnut cake (GNC) and soya bean meal (SBM) having the varying ratio of inclusion as in diet 1 (1:4.5:2.5), diet 2 (1:3.5:3.5), diet 3 (1:2.5:4.5) and diet 4 (1:3:4), respectively. These were compared with two primary commercial feeds which were coded as AF and TF and used for starter and finisher phases. Three hundred, one-day old Marshall breed chicks were randomly assigned to six dietary treatments (50 birds/treatment; 5 replicate/treatment) in a Completely Randomized Design. Parameters such as feed intake, weight gain, carcass traits, and relative weight of the internal organs and economic analysis of the chicks' production were measured. The daily weight gain of the broiler chickens fed diet 3 was significantly $(P<0.05)$ higher than those fed other diets, while the least daily feed intake was recorded in chicks fed diet 1. The broiler chickens fed with diet 5 , a commercial diet consumed higher $(P<0.05)$ quantity offeed, compared to those fed rest experimental diets; while the bird fed diet 1 recorded the least $(P<0.05)$ quantity of feed consumed. The broiler chickens fed diet 3 had better $(P<0.05)$ feed conversion to weight, when compared to those fed the rest diets. All the carcass traits and relative organs measured varied significantly $(P<0.05)$ with diets except the dressed weight. The test diets 3 and 4 had better cost/weight gain (\$239 and $\$ 228.9$ ) compared to the two commercial diets 5 (\$269.4) and 6 (\$296.8). It is therefore concluded that the simple mix ratio with FM:GNC: SBM ratios of 1:2.5:4.5 and 1:3:4 could be measured using local measuring items such as congos, milk tin, and tablespoon by peri-urban and backyard poultry farmers.

Keywords: backyard poultry, growth performance, feed cost, rural communities

\section{Une Évaluation d'un mélange d'ingrédients alimentaires simple et adaptable pour la production de poulets de chair}

'Agbede, J. O., ${ }^{1}$ Aboyewa, O. D., ${ }^{1}$ Ayeni, A. O. et ${ }^{*, 1,2}$ Oloruntola, O. D.

${ }^{\prime}$ Department of Animal Production and Health,

The Federal University of Technology, Akure, Nigeria.

${ }^{2}$ Department of Animal Science, Adekunle Ajasin University,

Akungba Akoko, Nigeria.

*Corresponding author: olugbenga.oloruntola@aaua.edu.ng,

$$
+2348035841626
$$

Résumé

Un essai d'alimentation de 42 jours a été mené pour évaluer le mélange d'ingrédients alimentaires simple et adaptable pour la production de poulets de chair. Les quatre régimes formulés ont été utilisés comme un simple diététique avec la farine de poisson (le 'FM'), le 


\section{Evaluation of simple and adaptable feed ingredient mix for broiler chickens production}

tourteau d'arachide (le 'GNC') et la farine de soja (le 'SBM') ayant le rapport variable d'inclusion comme $1: 4,5: 2,5)$, régime2 $(1: 3,5: 3,5)$, régime $3(1: 2,5: 4,5)$ et régime $4(1: 3$ : 4), respectivement. Ceux-ci ont été comparés aux aliments commerciaux primaires qui ont été codés comme AF et TF et utilisés pour les phases de commencement et de terminaison. Trois cents poussins de race Marshall, âgés d'un jour a été assignés au hasard à six traitements diététiques (50 oiseaux / traitement ; 5 répétitions / traitement) dans une conception complètement aléatoire. Des paramètres tels que la consommation alimentaire, le gain de poids, les caractéristiques de la carcasse et le poids relatif des organes internes et économiques l'analyse de la production des poussins a été mesurée. Le gain de poids quotidien des poulets de chair nourris avec le régime 3 était significativement $(P<0,05)$ plus élevé que ceux nourris avec d'autres régimes, tandis que la moindre prise alimentaire quotidienne a été enregistrée chez les poussins nourris au régime 1. Les poulets de chair nourris avec le régime 5, un régime commercial consommé une quantité d'aliments plus élevée $(P<0,05)$, par rapport aux régimes expérimentaux de repos nourris; tandis que le régime alimentaire pour oiseaux 1 enregistrait la moindre $(P<0,05)$ quantité d'aliments consommée. Les poulets de chair nourris avec le régime 3 avaient une meilleure conversion alimentaire $(P<0,05)$ en poids, par rapport à ceux nourris avec le reste. Tous les traits de carcasse et organes relatifs mesurés variaient significativement $(P<0,05)$ avec les régimes saufle poids habillé. Les régimes de test 3 et 4 avaient un meilleur gain de coût / poids (\#239 et $\$ 228$,9) par rapport aux deux régimes commerciaux $5(\$ 269,4)$ et $6(\$ 296,8)$. Il a donc conclu que le rapport de mélange simplifié avec $F M: G N C: S B 1: 3: 4$ pourrait être mesuré en utilisant des éléments de mesure locaux, comme les 'congos', le 'milkcup' et les cuillères à soupe par les éleveurs de volailles en milieu urbain et de basse-cour.

Mots clés :volaille de basse-cour, performance de croissance, coût des aliments, communautés rurales

\section{Introduction}

Poultry production is one of the most promising sources of additional income to family earnings and increases household protein intake and quick return from microlevel investment in developing countries (Oloruntola et al., 2016). Since broiler production is a fast-growing agricultural business in developing countries (Laseinde, 1982), the profitable production of broiler is essential. Smallholder poultry farming makes an important contribution to the livelihoods of households in most countries (Daghir, 1995). The growth and expansion of this smaller industry are dependent on reducing the reliance on commercial feed millers. Although, due to scarcity and high cost of some of the energy and protein sources of feed ingredients to backyard poultry farmers, researchers have tended to focus more on other feeds ingredients in their vicinity as alternatives. For instance, Pandi (2005) recorded the growth rate of village broilers fed with a commercial finisher feed diluted with 20 $80 \%$ of copra meal, a locally available food product. As a way of improvising, other smallholder farmers have opted to use home-made rations. This action has also led to the use of a wide array of conventional feeds with variations in nutritive values from renowned suppliers and reprocessing of specific diets now being experienced. Also, the use of nonconventional feeds with unknown nutritive values is increasing in broiler smallholder farmers. Some farmers have therefore resulted in substituting commercial diets for homemade feeds (Musamba, 2014). Homemade feeds usually lack consistency in the available nutrients (Sonaiya, 2008). Some farmers may not be knowledgeable 
on the nutritive values of the ingredients they use, and there are dangers of compromised performance. However, backyard poultry operations will be substantially improved if simple feed mix based on conventional feed ingredients is developed using locally available measuring items as an alternative to reliance on commercial feed recommended mode of use. The objective is to evaluate a straightforward and adaptable feed ingredient mix for broiler chickens by the backyard and peri-urban poultry farmers to reduce the over-dependence on commercial feeds.

\section{Materials and methods}

This study was carried out upon approval by the Research Committee of the Department of Animal Production and Health, Federal University of Technology (FUTA). The experiment was carried out at the Poultry Unit of the Teaching and Research Farm, FUTA. The University is located in the humid rain forest zone of Western Nigeria, with the tropical climate of broadly two seasons which are rainy season (AprilOctober) and dry season (NovemberMarch). The temperature throughout the year ranges from $21^{\circ} \mathrm{C}$ to $29^{\circ} \mathrm{C}$. The annual rainfall varies from $1,150 \mathrm{~mm}$ to $2,000 \mathrm{~mm}$ in the northern areas within coordinates $7^{0} 10^{\prime} \mathrm{N} 5^{\circ} 05^{\prime} \mathrm{E}$. The laboratory analyses were carried out at the Department of Animal Production and Health Nutrition Laboratory of the same institution.

\section{Local measuring items}

Local measuring items commonly used in Nigeria, i.e. congo, milk tin, and tablespoon were used as appropriate in measuring various feed ingredients. The macro ingredients such as maize, groundnut cake (GNC), fish meal (FM), and soybean meal (SBM) were measured using congo and milk tin while the microingredients like lysine, methionine, salt, and premix were measured using a tablespoon.
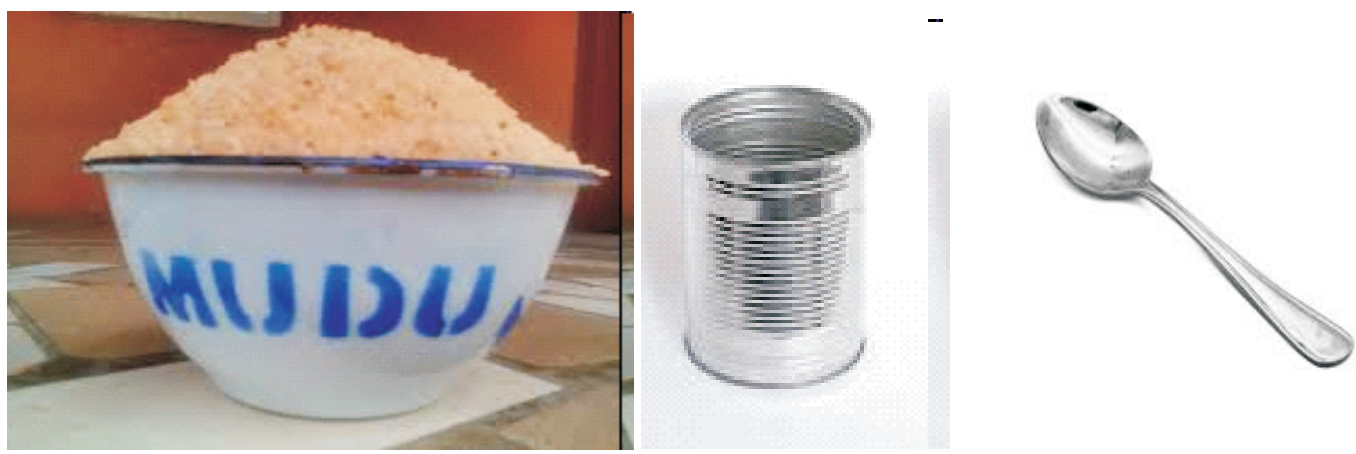

Photo 1: Congo, milk tin and tablespoon used for measuring food in Nigeria local markets

\section{Experimental diets}

Six dietary treatments (four formulated and two commercial diets) were used for the trial. The four formulated diets were used as a straight diet with the fish meal (FM), groundnut cake (GNC) and soya bean meal (SBM) having the varying ratio of inclusion as in diet $1(1: 4.5: 2.5)$, diet 2 (1:3.5:3.5), diet 3 (1:2.5:4.5) and diet 4 (1:3:4), respectively. These were compared with two primary commercial feeds which were coded as AF and TF and used for starter and finisher phases. The varying ratios for fish meal, groundnut cake, and soya bean meal in each of the diet, including other ingredients fed to the birds are detailed in Table 1. The proximate composition of the experimental diets was determined (AOAC, 2002). 


\section{Evaluation of simple and adaptable feed ingredient mix for broiler chickens production}

Table 1: Ratios of feed ingredients used for the experimental diets

\begin{tabular}{|c|c|c|c|c|c|c|}
\hline Ingredients & Diet 1 & Diet 2 & Diet 3 & Diet 4 & Diet 5 & Diet 6 \\
\hline \multicolumn{7}{|l|}{ Macro (congo) } \\
\hline Maize & 15 & 15 & 15 & 15 & AF1 & TF2 \\
\hline Ground nut cake & $41 / 2$ & $3 \frac{1}{2}$ & $2 \frac{1}{2}$ & 3 & & \\
\hline Soybean meal & $2 \frac{1}{2}$ & $3 \frac{1}{2}$ & $4 \frac{1}{2}$ & 4 & & \\
\hline Fish meal & 1 & 1 & 1 & 1 & & \\
\hline Micro (milk tin) & & & & & & \\
\hline Dicalcium phosphate & $61 / 4$ & $61 / 4$ & $61 / 4$ & $61 / 4$ & & \\
\hline Oyster shell & $23 / 4$ & $23 / 4$ & $23 / 4$ & $23 / 4$ & & \\
\hline Premix & $3 / 4$ & $3 / 4$ & $3 / 4$ & $3 / 4$ & & \\
\hline Methionine & $3 / 8$ & $3 / 8$ & $3 / 8$ & $3 / 8$ & & \\
\hline Lysine & $3 / 8$ & $3 / 8$ & $3 / 8$ & $3 / 8$ & & \\
\hline Salt & $3 / 4$ & $3 / 4$ & $3 / 4$ & $3 / 4$ & & \\
\hline Vegetable oil & $83 / 4$ & $83 / 4$ & $83 / 4$ & $83 / 4$ & & \\
\hline Total & 25 congos & 25 congos & 25 congos & 25 congos & & \\
\hline
\end{tabular}

\section{Response criteria}

Feed intake was recorded daily, and body weight changes every week. The feed intake and the weight changes were used to determine the feed conversion ratio during the period of the trial.

At the end of the feeding trials (42 days), the birds were starved overnight to empty their crop, and four (4) birds were randomly selected from each replicate. They were weighed, stunned, and slaughtered by cutting the jugular veins in the neck region of the birds. After bleeding the chickens, carcasses were scalded in hot water (50$55^{\circ} \mathrm{C}$ ) for 30 seconds. Dressed, eviscerated, and dissected into parts. Live, dressed, liver, gizzard, heart, lungs, wings, neck, back, thigh, drumstick, and breast weights were taken and recorded. The dressed weight was expressed as a percentage of the live weight while others were expressed as grams per kilogram body weight.

The economic and cost of producing the experimental diets were estimated based on current market prices for the ingredients at the time of the experiment. Thus, the various cost indices were calculated accordingly. The cost of feed consumed is equal to the cost of $1 \mathrm{~kg}$ of a feed multiplied by the total feed consumed while the feed cost per kg body weight is equal to the cost of feed consumed divided by the final body weight of birds.

\section{Statistical analysis}

All data collected were subjected to one way Analysis of variance using SPSS version 20, where differences were significant, means were separated with the Duncan;s Multiple Range Test of the same statistical package (SPSS).

\section{Results}

The proximate composition of the experimented diets is presented in Table 2. The crude protein of diet 5 was the highest compared to other diets; while the least was recorded in diet 6 . Besides, there were marginal differences in the percentage of the other nutrients in the various diets.

Table 2: Proximate composition (\% DM) of the experimental diets

\begin{tabular}{|c|c|c|c|c|c|c|c|c|}
\hline & Diet & Diet & Diet & Diet & Diet 5 & Diet 5 & Diet 6 & Diet 6 \\
\hline Nutrients & 1 & 2 & 3 & 4 & AF1S & $\mathrm{AF} 1 \mathrm{~F}$ & TF2S & TF2F \\
\hline Crude protein & 21.30 & 21.20 & 20.60 & 20.60 & 23.7 & 19.5 & 23.8 & 19.65 \\
\hline Crude fibre & 5.30 & 6.52 & 4.72 & 5.28 & 3.39 & 2.90 & 3.67 & 3.09 \\
\hline Ether extract & 9.21 & 6.96 & 8.70 & 7.59 & 6.51 & 3.10 & 5.49 & 4.94 \\
\hline Ash & 4.16 & 7.84 & 5.48 & 4.61 & 7.32 & 6.82 & 5.33 & 6.85 \\
\hline Nitrogen free extract & 60.0 & 57.5 & 60.5 & 61.9 & 59.1 & 67.7 & 61.8 & 65.5 \\
\hline
\end{tabular}




\section{Agbede, Aboyewa, Ayeni and Oloruntola}

Table 3 shows the growth performance parameter of age 42 days broiler chicken fed with a simple mix (diets 1 to 4) and commercial diet (diets 5 and 6). The daily weight gain that was recorded in broiler chickens fed diet 3 was significantly $(\mathrm{P}<0.05)$ higher than other diet, while the least daily feed intake was recorded in the birds fed diet 1 . The chicks fed diet 5 consumed higher $(\mathrm{P}<0.05)$ quantity of feed, compared to those fed other diets; while chicks fed diet 1 recorded the least $(\mathrm{P}<0.05)$ quantity of feed. The broiler chickens fed diet 3 had better $(\mathrm{P}<0.05)$ feed conversion to weight, when compared to those fed the other diets. The least feed conversion was recorded in the broiler chickens fed diet 1 .

Table 3: Performance of broiler chickens fed the simple, adaptable diets and commercial diets ( $1-42$ days of age)

\begin{tabular}{lllllllll}
\hline & \multicolumn{7}{c}{ Treatment diets } \\
\cline { 2 - 7 } Parameters & Diet 1 & Diet 2 & Diet 3 & Diet 4 & Diet 5 & Diet 6 & SEM & P value \\
\hline Initial weight $(\mathrm{g} / \mathrm{b})$ & 38.6 & 38.8 & 38.8 & 38.7 & 38.8 & 38.6 & 0.22 & 1.00 \\
Final weight $(\mathrm{g} / \mathrm{b})$ & $1631^{\mathrm{e}}$ & $2027^{\mathrm{d}}$ & $2531^{\mathrm{a}}$ & $2427^{\mathrm{b}}$ & $2467^{\mathrm{b}}$ & $2209^{\mathrm{c}}$ & 76.01 & 0.00 \\
Daily weight gain $(\mathrm{g} / \mathrm{b})$ & $28.4^{\mathrm{e}}$ & $35.5^{\mathrm{d}}$ & $44.5^{\mathrm{a}}$ & $42.7^{\mathrm{b}}$ & $43.4^{\mathrm{b}}$ & $38.8^{\mathrm{c}}$ & 1.35 & 0.00 \\
Daily feed intake $(\mathrm{g} / \mathrm{b})$ & $89.3^{\mathrm{e}}$ & $104.2^{\mathrm{b}}$ & $102.2^{\mathrm{c}}$ & $92.6^{\mathrm{d}}$ & $110.2^{\mathrm{a}}$ & $1027^{\mathrm{c}}$ & 1.73 & 0.00 \\
Feed conversion ratio & $3.14^{\mathrm{a}}$ & $2.93^{\mathrm{b}}$ & $2.31^{\mathrm{e}}$ & $2.17^{\mathrm{f}}$ & $2.54^{\mathrm{d}}$ & $2.65^{\mathrm{c}}$ & 0.81 & 0.00 \\
\hline
\end{tabular}

Diets 1 to 4: Simple, adaptable feed ingredients mix; Diets 5 and 6: Commercial feeds; SEM: Standard error of the means, ${ }^{a, b, c, d, e}$ Means with different superscripts within a row differ significantly $(\mathrm{P}<0.05)$.

The carcass characteristics and relative internal organ weights of the broiler chickens fed the simple, adaptable diets and the commercial diets are shown in Table 4. The parameters measured were similar $(\mathrm{P}>0.05)$ across the diets except for the wing, drumstick, neck, gizzard, heart, and belly fat. The wing of the birds fed diets 5 , and 6 were similar $(\mathrm{P}>0.05)$ to those fed diet 1 and 4 , but significantly $(\mathrm{P}<0.05)$ heavier than those fed the rest diets. The drumstick weight of the birds fed diet 1 was similar to those fed diets 2,5 , and 6 but significantly $(\mathrm{P}<0.05)$ heavier than those fed diets 3 and 4 . The neck of the birds fed the adaptable diets (diets 1-4) were heavier $(\mathrm{P}<0.05)$ than those fed the commercial diets (diets 5 and 6 ). The gizzard of the birds fed diet 1 was heavier $(\mathrm{P}<0.05)$ than those fed the rest diets. The heart and belly fat of the birds fed diet 1 were similar to those fed diets 3 and 5 but were heavier $(\mathrm{P}<0.05)$ than those fed the diets 1,2 , and 3 .

Table 4: Carcass traits and relative internal organ weightsof broiler chickens fed the simple, adaptable diets and the commercial diets (age 42 days)

\begin{tabular}{lllllllll}
\hline & \multicolumn{7}{c}{ Treatment diets } \\
\cline { 2 - 6 } Parameters & Diet 1 & Diet 2 & Diet 3 & Diet 4 & Diet 5 & Diet 6 & SEM & P value \\
\hline Dressed \% & 90.67 & 90.50 & 88.84 & 89.80 & 90.42 & 89.32 & 0.28 & 0.37 \\
Wing & $79.55^{\mathrm{abc}}$ & $78.29^{\mathrm{bc}}$ & $77.81^{\mathrm{c}}$ & $80.24^{\mathrm{ab}}$ & $81.69^{\mathrm{a}}$ & $80.86^{\mathrm{a}}$ & 0.41 & 0.01 \\
Drumstick & $100.53^{\mathrm{a}}$ & $99.32^{\mathrm{ab}}$ & $96.42^{\mathrm{c}}$ & $97.14^{\mathrm{bc}}$ & $98.28^{\mathrm{abc}}$ & $98.35^{\mathrm{abc}}$ & 0.41 & 0.02 \\
Breast & 186.07 & 195.77 & 189.71 & 189.26 & 196.57 & 196.70 & 1.47 & 0.13 \\
Thigh & 99.62 & 101.05 & 95.49 & 99.29 & 102.15 & 99.52 & 0.91 & 0.43 \\
Neck & $41.96^{\mathrm{a}}$ & $40.98^{\mathrm{a}}$ & $42.74^{\mathrm{a}}$ & $41.13^{\mathrm{a}}$ & $37.62^{\mathrm{b}}$ & $37.54^{\mathrm{b}}$ & 0.58 & 0.01 \\
Back & 152.19 & 153.08 & 158.73 & 159.86 & 153.91 & 146.76 & 1.62 & 0.19 \\
Gizzard & $22.08^{\mathrm{a}}$ & $20.37^{\mathrm{b}}$ & $19.42^{\mathrm{b}}$ & $19.51^{\mathrm{b}}$ & $19.50^{\mathrm{b}}$ & $19.60^{\mathrm{b}}$ & 0.25 & 0.00 \\
Liver & 15.16 & 22.97 & 21.84 & 19.86 & 19.45 & 20.69 & 0.97 & 0.27 \\
Lung & 5.24 & 5.35 & 5.56 & 5.59 & 5.33 & 5.64 & 0.11 & 0.91 \\
Heart & $4.89^{\mathrm{b}}$ & $4.97^{\mathrm{b}}$ & $4.74^{\mathrm{b}}$ & $5.10^{\mathrm{ab}}$ & $5.44^{\mathrm{a}}$ & $5.38^{\mathrm{a}}$ & 0.74 & 0.01 \\
Belly fat & $17.35^{\mathrm{b}}$ & $18.64^{\mathrm{b}}$ & $19.74^{\mathrm{b}}$ & $24.72^{\mathrm{a}}$ & $25.02^{\mathrm{a}}$ & $21.95^{\mathrm{ab}}$ & 0.86 & 0.01 \\
\hline
\end{tabular}

Diets 1 to 4: Simple, adaptable feed ingredients mix, Diets 5 and 6; Commercial feeds, SEM: Standard error of the means, ${ }^{\text {a,b,c }}$ Means with different superscripts within a row differ significantly $(\mathrm{P}<0.05)$. 
Figure 1 shows the cost of the experimental diets, feed consumed, and feed cost/weight gain. Diet The test diets 3 and 4 had better cost/weight gain ( $\$ 239$ and $\$ 228.9$ ) compared to the two commercial diets 5 ( 269.4) and 6( 296.8).

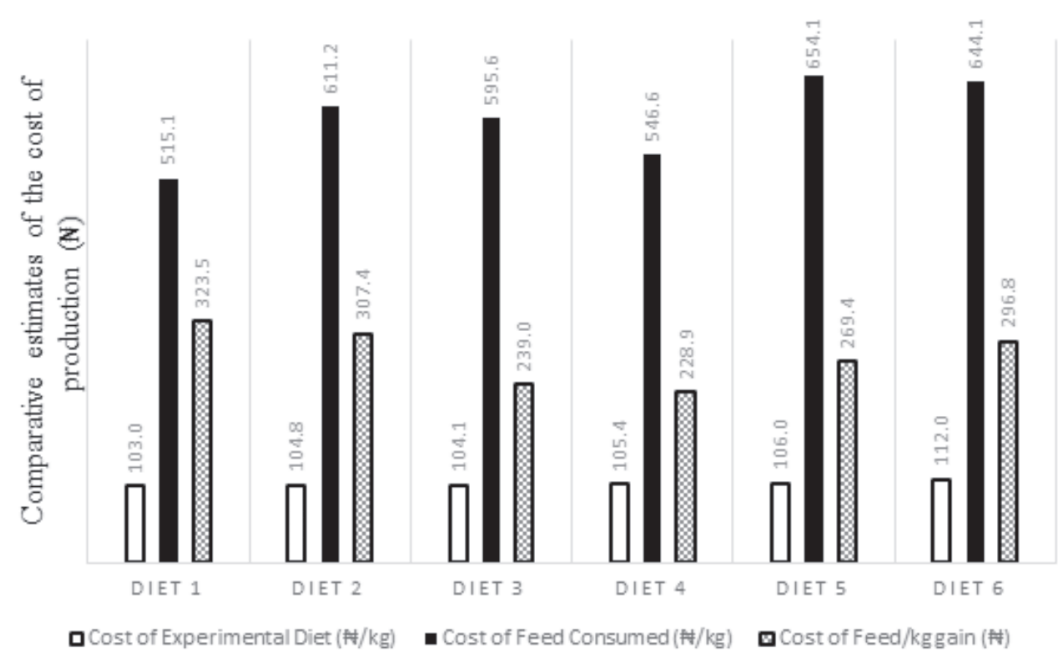

Figure 1: Average costs of the experimental diets, feed consumed and feed cost/weight gain (1-42 days)

\section{Discussion}

The superior daily weight gain recorded for birds fed diet 3 (an adaptable formulated diet) over other chickens fed the other diets suggests the nutritional balance in the diet especially the micronutrients such as the amino acid balance. This may also explain the reason for the feed conversion ratio recorded for this group of birds. Khattab and Arntfield (2009) suggested that it is advisable to enhance the protein and amino acid content of the diet through readily available and accessible plant protein sources, especially legumes to improve the nutritional status. It is well documented that cereal proteins are deficient in certain essential amino acids, particularly in lysine (Anjum et al., 2005) whereas legumes contained an adequate amount of lysine (Sai-Ut et al., 2009). The nutritional quality depends upon specific amino acids and their physiological utilization after digestion, absorption, and mandatory minimum rates of oxidation
(Longnecker et al., 2002). The similar dressed percentage, breast, thigh, and relative back weights recorded across the diets suggests that both formulated diets using local measurements and the commercial diets promoted similar carcass cut in the birds. Although, there exist differences in the relative weights of the wing, drum stick, neck, heart, and belly fat of the birds across the various experimental diets. These variations did not follow a particular trend.

The cost of feed/kg gain ( ) of birds fed diet 3 when compared with those of chickens fed diets 5 and 6, reduced by' 30.4 and' 57.8 . This translates to saving of about ' 30,400.00 and' $57,800.00$ per tonne of feed for the farmers thus implying that farmers stand to gain more economically using diet 3 which is formulated from simple and adaptable feed ingredients mix. This as envisaged would encourage broiler production and increase profitability, especially by peri-urban and backyard 
poultry farmers.

\section{Conclusion}

It is therefore concluded that the simple mix ratio with FM: GNC: SBM ratios of $1: 2.5: 4.5$ and $1: 3: 4$ could be measured using local measuring items such as congos, milk tin, and tablespoon by periurban and backyard poultry farmers. This is expected would lead to a reduction in the cost of broiler chicken diets among less literate farmers who depends on the commercial feed and feed millers for their feed accusation.

\section{References}

Anjum, F. M., Ahmad, I., Butt, M. S., Sheikh, M. A. and Pasha, I. 2005. Amino acid composition of spring wheat and losses of lysine during chapatti baking. Journal of Food Composition Analysis, 18 ( 6 ) : $523-532$. https://doi.org/10.1016/j.jfca.200 4.04.009

AOAC 2002. Association of Analytical Chemists. Official Method of Analysis. 18th edition. Washington DC., USA.

Daghir, N. J. 1995. Poultry Production in Hot Climates. CAB International, Wallingford, UK.

Khattab, R. Y. and Arntfield, S.D. 2009. Nutritional quality of legume seeds as affected by some physical treatmentsAnti-nutritional factors. LWT- Food Science Technology. $42: 11113$ - 11118 . D O I : 10.1016/j.lwt.2009.02.004

Laseinde, E. A. O. 1982. Technical Guide to Poultry Production. Division of Agricultural Colleges Newsletter. 1:4 (14-18).
Longnecker, N., Kelly, R. and Huang, S. 2002. The lentil lifestyle-Health benefits of lentils and their use in diets. In Proceedings of Lentil Focus: National Conference, Horsham (Victoria). Pp: 58-59.

Musamba, S. 2014. The Nutritionist and former Sales Manager. National Foods Limited, 13 Foundry Road, Aspindale, Harare.

Oloruntola, O. D., Ayodele, S. O., Agbede, J. O. and Oloruntola, D. A. 2016. Effect of feeding broiler chickens with diets containing Alchornea cordifolia leaf meal and enzyme supplementation. Archivos de Zootecnia, 65(252): 489-498.

Pandi, J. 2005. Dilution of broiler finisher feed with copra meal. $P N G$ Journal of Agriculture, Forest, and Fisheries. 48: 1-2.

Sai-Ut, S., Ketnawa, S., Chaiwut P. and Rawdkuen, S. 2009. Biochemical and functional properties of proteins from red kidney, navy, and adzuki beans. Asian Journal of Food Agro-Industry, 2(04):493 504.

Sonaiya, E. B. 1996. Employment/ income generation and skill development through rural poultry development. Proceedings XX World Poultry Congress. New Delhi, India.1: 1722.

Received: $17^{\text {th }}$ August, 2020 Accepted: $20^{\text {th }}$ November, 2020 